\title{
TOWARD AN AFFECTIVE SENSE OF LIFE: Artificial Intelligence, Animacy, and Amusement at a Robot Pet Memorial Service in Japan
}

\author{
DANIEL WHITE \\ University of Cambridge \\ (iD https://orcid.org/0000-0003-2866-6587 \\ HIROFUMI KATSUNO \\ Doshisha University \\ (iD) https:/ / orcid.org/0000-0003-4133-2346
}

In the early spring of 2018 at a rural Buddhist temple in Japan, the local priest, Ōi Bungen, is conducting a memorial service for 109 pet robots. Each one the size and with the features of a small dog, the robots are lined up alongside one another on a long, three-tiered altar covered in white linen, facing the priest and the crowd of about fifty people who have gathered to observe. The priest chants rapidly from the Lotus Sutra at the opening of the ceremony, comforting the spirits of the robots, before, with the following steps, he sets them free from their mechanical bodies. The priest moves methodically down the row, waving a ceremonial set of prayer beads (nenju) typical of these services in the Nichiren Buddhist tradition. When finished, he sits and reads a prayer (ekōmon) that dedicates the merit of the service to the departed spirits of the robots. He continues with informal words to the guests, thanking them for attending and sharing his reflections on what we can learn about life and Buddha-nature (busshō) from our robot companions. The service ends with a closing sutra recitation, this time not from the priest but from the small humanoid robot Palro, who is accompanied by two canine-like robot assistants. Their high-pitched voices, mechanical but by no 
means lifeless, pierce the warm, damp air and mix with the lingering incense and musty smell of the cedar structure and tatami mats of the temple floor. It is an enchanting, reverent, and intoxicating atmosphere, and judging by the soft smiles on the faces of the attendees, nearly everyone can feel it. Motivated to piece it all together, I immediately start thinking . . .

"Thinking is stupid! Thinking is boring! I feel! Not thinking; feeling!" Ōi leaned forward with a raised finger when he vigorously proclaimed these words to me (Daniel White) in a private conversation a week after the ceremony. ${ }^{1} \mathrm{He}$ then sat back and smiled. The exaggerated disparagement of thought had been half tongue-in-cheek. After all, Ōi could hardly be taken for being anti-intellectual, despite what others may first read into his jocular joie de vivre, his amusing if meandering stories, and his endearing self-deprecation: "By the way, do you know the three most boring things in life?" he asked, setting me up again: "School lectures, the national public broadcaster's live parliamentary feed, and stories from Buddhist priests.” We both laughed. But I wasn't fooled. In an earlier conversation, on learning that I was an anthropologist studying artificial intelligence (AI), Ōi mentioned to me some of his favorite writers: Émile Durkheim, Henri Bergson, Norbert Wiener. "Wiener was a genius!" he proclaimed. Even as we sat talking then, about a dozen books Ōi was currently reading were laid out in front of us, belying his modesty if, in their scope, still honoring his humility. Among them were David Bohm's The Undivided Universe: An Ontological Interpretation of Quantum Theory; Brian Green's The Fabric of the Cosmos; a biography of the fractal mathematician Benoit Mandelbrot; and an introductory volume on big data and AI. "Isn't it amazing all this information is available in Japanese?” he said, genuinely surprised. "I don't really understand it, though," he qualified with a chuckle. Ōi stood by his commitment to feeling, or more precisely, to jikkan, a word composed of the characters for “reality” (実) and “feeling” (感) that suggests an act of sensing, knowing, or realizing with the body. Yet he was hardly hostile to analytical thought. The trick for him was how to bring feeling and thinking together. For Ōi, nothing did this better than Sony's pet-styled robot, which made for one of the reasons he began conducting for them the Buddhist memorial service called kuyō.

The mechanical pets for which Ōi conducts kuyō are named AIBO (Artificially Intelligent RoBOt). Importantly, the acronym also plays on the Japanese word aibo, meaning "friend” or "companion." 2 Created in Sony's Computer Science Laboratory in the mid-1990s and released in 1999, AIBO exceeded all expectations. The first five thousand models made available in Japan sold out in twenty minutes (Ōtsuki 2015, 3). They attracted not only the target audience of thir- 
ty-something male technophiles but also, surprisingly, women in their fifties and older. "Owners" (ōnā), as they called themselves, dressed their AIBO in clothing and gathered with friends to share stories and watch AIBO play. They were enchanted when AIBO learned a new trick or did something unexpected. Many felt their AIBO had its own personality, spirit, or heart (kokoro). And when AIBO began to grow old, they naturally sought professional care for what had become an important member of their family (Kubo 2010). However, when due to shifting priorities and economic challenges Sony discontinued its AIBO line in 2006, the company also stopped servicing those models in need of repair, leaving many customers distraught.

Recognizing the deep attachment owners had cultivated for their AIBO, a former Sony employee named Norimatsu Nobuyuki set up his own operation, the playfully named A-FUN Company (A-fan kabushiki gaisha), to meet consumers' needs in a way that respected owners' feelings for their robot kin. At his service center employees use words like "surgery" instead of "repair" (Knox and Watanabe 2018, 2022), and they refer to the other AIBO models from which parts are borrowed as "organ donors." For those owners whose AIBO are beyond repair but could potentially become donors, Norimatsu sought help from an "interesting Buddhist monk" he heard talking one day on a local radio program to offer a memorial service to assist those who found it difficult to part with their robot family members. ${ }^{3}$ A technophile in his own right, Ōi happily obliged. At the end of each ceremony officiated by Ōi, the AIBO souls are released from their robot bodies and employees of A-FUN Company — who outnumber the owners in attendance - pack up the robots in boxes to send them to the company's service center to find new life in other ailing AIBO bodies. ${ }^{4}$ According to A-FUN's Norimatsu, the ceremonies have contributed not only to the care of his customers and the success of his company but also to Sony's decision to re-release AIBO in 2018, equipped with the latest artificial intelligence. Completing a circuit, ceremonies mourning AIBO death cultivate capacities of care for lifelike agents that guide the ongoing design, application, and even understanding of artificial life in Japan.

This article returns to the phenomenon of memorial services in Japan for Sony's companion robot AIBO, first popularized in 2015, in order to rethink - or better, following the advice of our lead interlocutor Ōi, to re-feel — the significance of the sensations artificial agents playfully and amusingly evoke in certain robot users. We take up this admittedly marginal scene of ethnographic encounter not to revisit adaptations of animism from Japanese antiquity to the present but rather to contextualize animacy's significance within emerging markets for mass-produced 


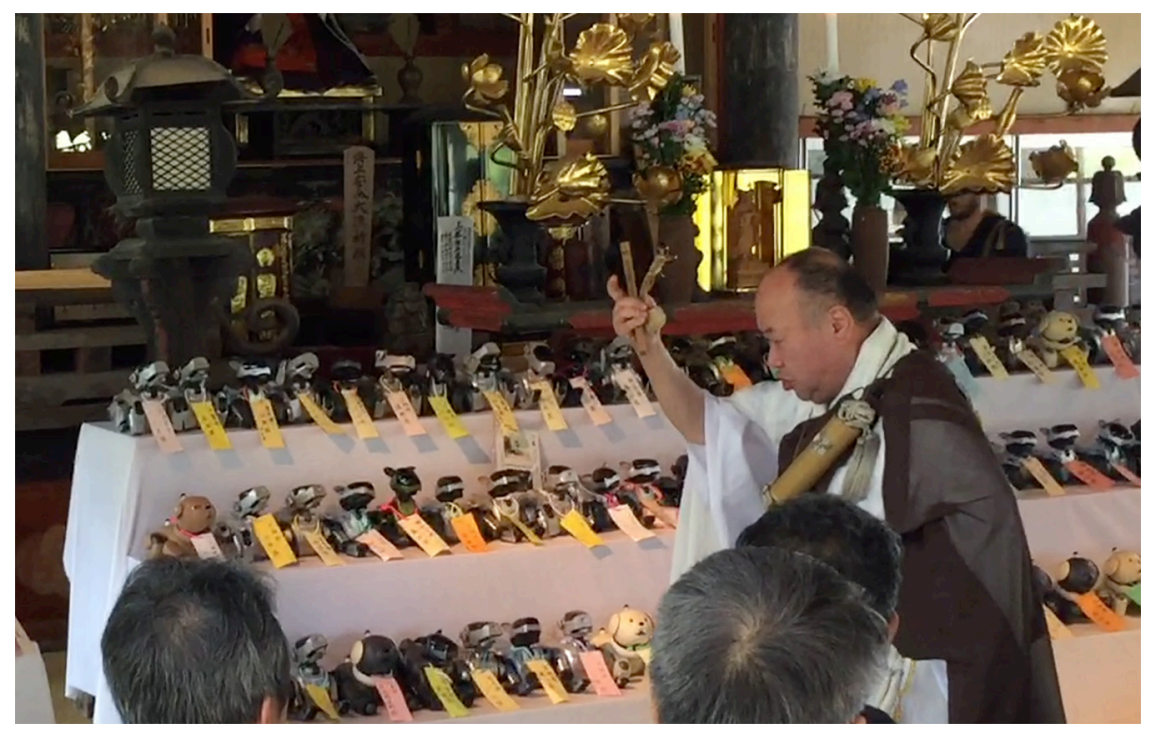

Figure 1. AIBO and Ōi Bungen at AIBO kuyō, April 2018. Photo by Daniel White.

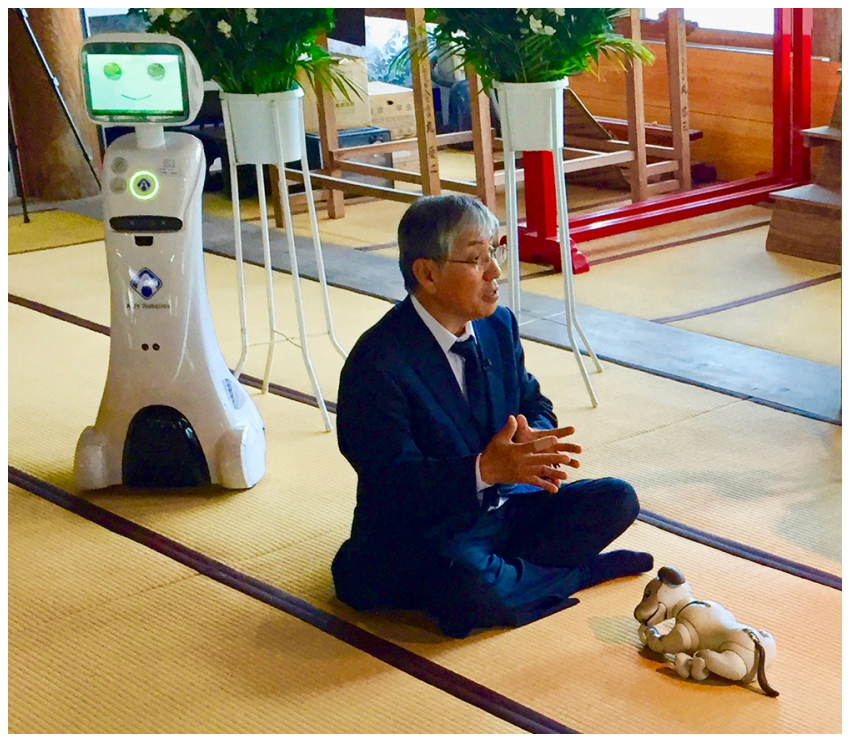

Figure 2. A-FUN Corporation's Norimatsu Nobuyuki with Sony's 2018 aibo and service robot by AMY Robotics. Photo by Daniel White.

robots. In this sense our study is relevant to emerging work theorizing animation (Silvio 2010, 2019; Manning and Gershon 2013; Nozawa 2013; Gershon 2015; Hales 2019), while contributing an affective focus to it. The robot users we interact with are positioned in prominent sites of what we call "robot sensemaking." These sites refer to highly publicized places and practices of human-robot 


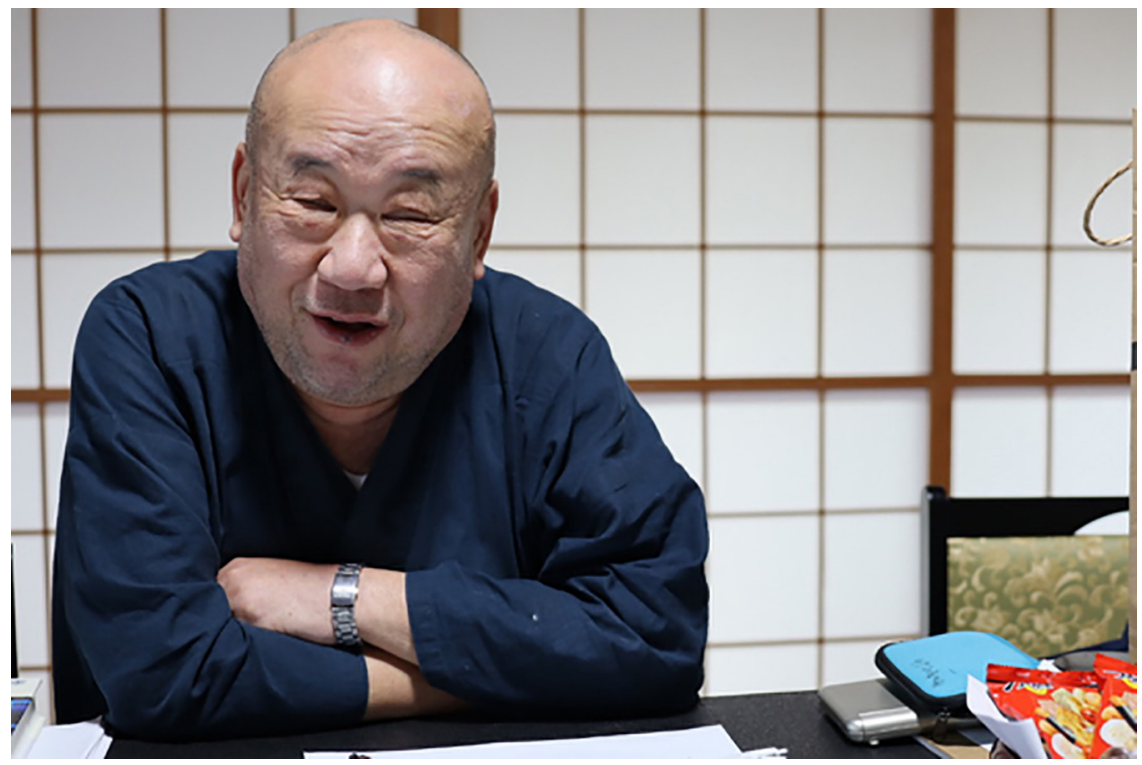

Figure 3. Ōi Bungen in conversation. Photo by Daniel White.

interaction in which certain discursive readings of otherwise undefined but nonetheless socially conditioned sensations, or affects, solidify into energetic clusters of somatic-semantic associations, or emotions. Drawing on collaborative fieldwork in Japan with robotics engineers, marketers, and, most important for this study, Buddhist priests integrating social robots into ritual settings, we explore how an openness to the enchantment of life as affect - as the ability to be moved and, critically, amused by others, artificial or otherwise-develops in conjunction with the production of entertainment robots. Most importantly, we focus on how animacy, or the lifelike quality of robots, is targeted for augmentation by researchers in artificial intelligence. While long-standing debates in Japan attribute a contemporary sensitivity to animacy either to a cultural tradition of quintessentially Japanese users uniquely receptive to forces of animism inhabiting inanimate objects or to the technological capacity of engineers to model universal properties of life in mechatronics, this article takes a different view. We understand animacy as a mutable capacity_ exercisable, relationally produced, and responsive to demands of historical, social, and market-driven technoscientific change. We illustrate a social production of animacy by casting AIBO memorial services against the backdrop of companion-robot engineering practices in which AI is applied to augment what engineers call an artificial agent's "sense of life" (seimeikan). We suggest this sense of life can be observed as an emic principle of robot design and applied as an etic 
description of how robot users sense robot animacy through a mode of relating that privileges feeling. Central to this feeling is amusement, a cultivated sense of openness to treating robots as alive that incorporates aspects of play and enchantment. By showing how amusement becomes central to both seimeikan design and human-robot interaction, we argue that animacy in the age of AI-driven entertainment robotics in Japan becomes characterized by an embodied sense that leverages the playful pleasure of human-robot care to new, multiple, and even seemingly contradictory understandings of life, such as that of a living robot.

This focus on affect affords new possibilities, we think, not only for tracing technosocial transformations of animacy and intimacy in Japan but also for advancing anthropological theory more generally. Thus, after discussing practices of building and evaluating AIBO's seimeikan among robotics engineers and organizers of AIBO memorial services, we conclude by exploring how exercising affect as a method of tracing new formulations of knowledge can move the anthropology of affect beyond some of the analytical problem-solving approaches that have rendered ethnographic explorations of affect too much a problem of theoretical puzzling and not enough one of method. In short, we argue that while anthropologists have offered ample analytical answers to a problematization shared by interlocutors in Japan and elsewhere of how manufactured objects such as robots seem alive, they have not fully accepted affect as one legitimate response, nor fully explored ways of relating to affect as social fact. We suggest that approaching affect as method offers an effective way to study human-robot interaction given the prominent roles that artificial agents are coming to play in increasingly machine-inclusive multispecies societies.

\section{A SENSE OF LIFE IN ENTERTAINMENT ROBOTS WITH HEART}

AIBO kuyō and the priest Ōi offer an exemplary illustration of how an affective openness to amusement and play can foster a means of caring for and through companion robots that seem alive. Yet as Ōi would readily admit, this capacity is cultivated less through the idiosyncrasies of his personality or the playfulness of Buddhism's sometimes negative dialectics than through experimentation with entertainment robots equipped with AI. In a 2001 paper published in Japan's major scientific journal of artificial intelligence, Fujita Masahiro, the leading artificial intelligence expert collaborating on AIBO's design, cited the important role that "robot entertainment" (robotto entāteimento) could play in leveraging industry toward scientific research (Fujita 2001, 399). Fujita and colleagues have also called for the creation of a new industry focused specifically on robot entertainment. 
They write, "We strongly believe that after the Gold Rush of the Internet and cyber-space, people will eagerly seek real objects to play with and touch. Robot Entertainment provides tangible physical agents and an unquestionable sense of reality" (Fujita and Kitano 1998, 8). For Fujita and other engineers at Sony, constructing this tangible "sense of reality" (seimeikan) in AIBO, or what we alternatively translate as a "sense of life," was important not only for providing entertainment through a commodity but also for realizing "technological breakthroughs" (gijutsu no brēkusurū) in AI (Fujita 2001, 399). ${ }^{5}$ Other examples of agents designed with a sense of life within a growing market for companion robots include the humanoid robot Pepper, which the mobile giant SoftBank announced in 2014 as "the world's first personal robot that reads emotions" (SoftBank 2014); Palro, a conversation robot designed by Fujisoft to facilitate conversation with elderly users; LOVOT, a "duo" of two furry robots on wheels that the company Groove X says are "powered by love," as well as by their proprietary "Emotional Robotics" technology (Groove X n.d.); and Sony's latest AIBO reincarnate, aibo (rebranded in lowercase), re-released twelve years after discontinuation to great anticipation in early 2018.

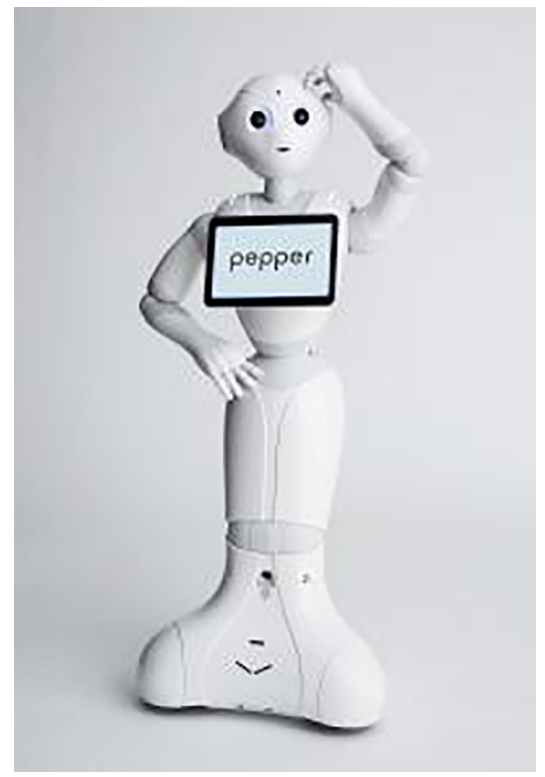

Figure 4. Pepper the Robot, by SoftBank Robotics.

These new companion or entertainment robots are marketed to different consumers in contemporary Japan, covering a variety of demographic and market niches. However, robot producers also have a common understanding that their 


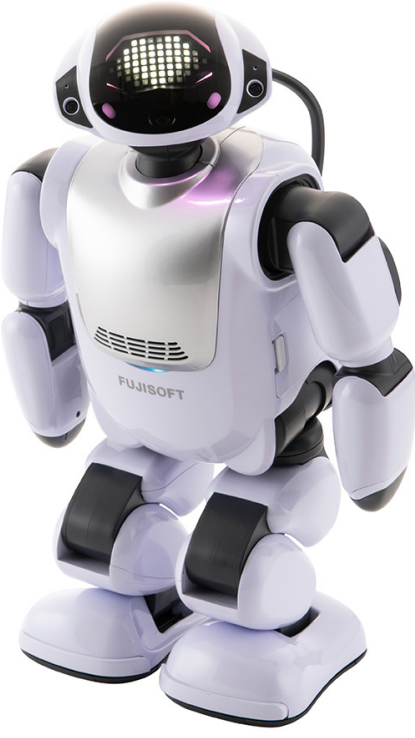

Figure 5. Palro, by FUJISOFT.

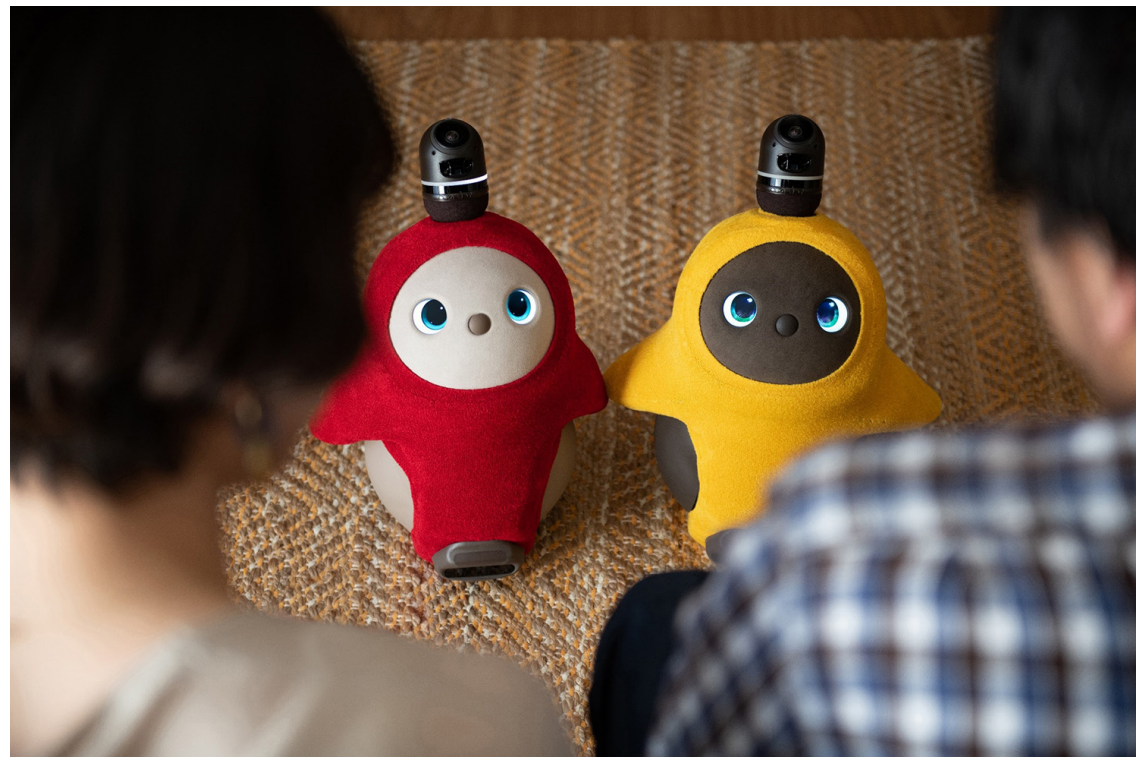

Figure 6. LOVOT, by GROOVE X.

products address a problematic deficit in intimacy in Japanese society, brought about by nearly three decades of a stagnating economy since the collapse of Japan's asset bubble in 1992 and the attenuation of social bonds tied to traditional struc- 


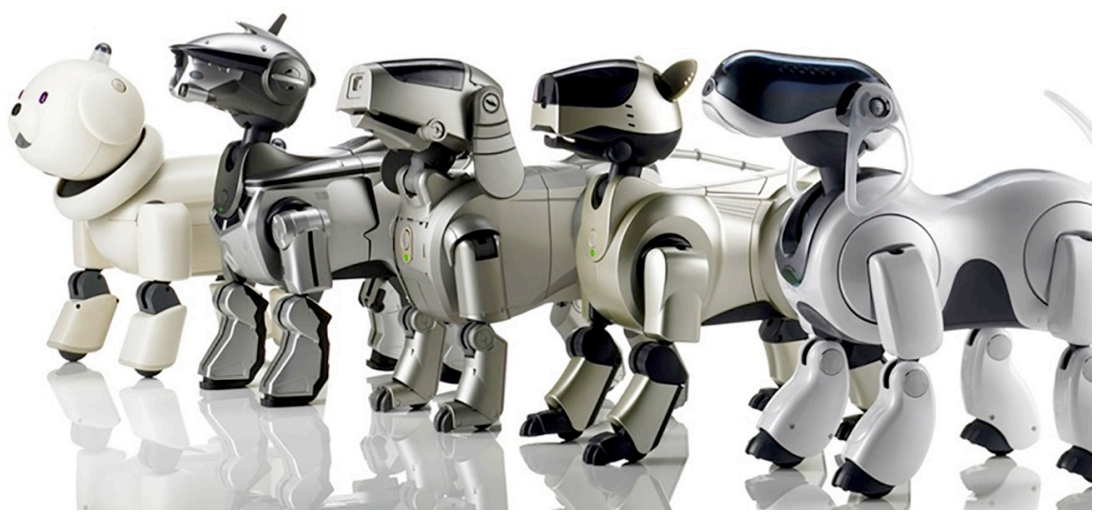

Figure 7. AIBO models, 1999-2006, by Sony.
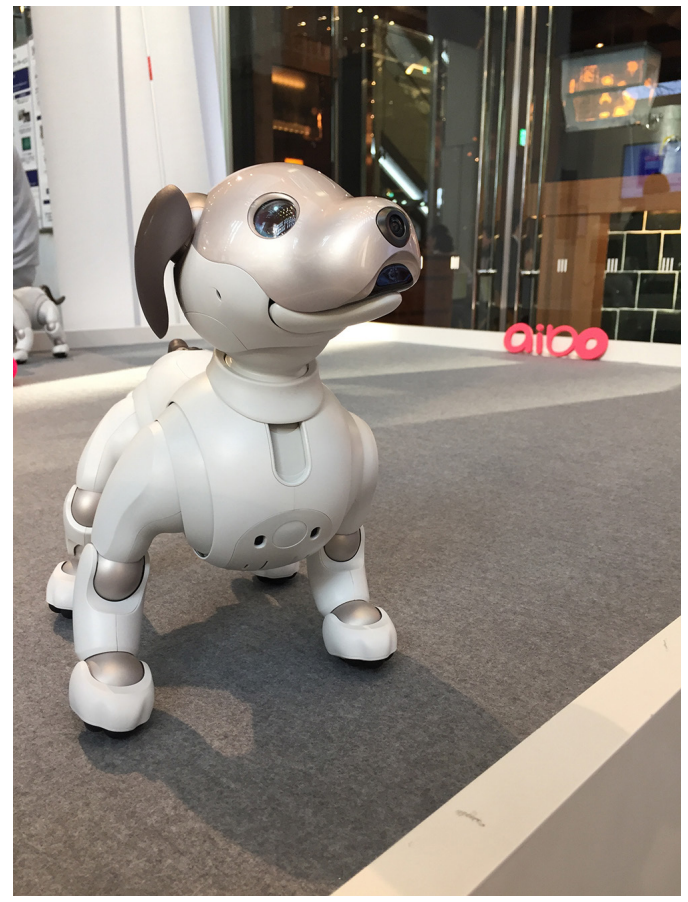

Figure 8. Sony's 2018 model aibo. Photo by Daniel White.

tures of family and lifetime employment (Allison 2013). Building on an emerging market in goods that provide healing (iyashi) in the wake of crisis, which includes a surge in living pets that Paul Hansen (2013) argues are indicative of a "postfamilial Japan,” engineers imagine robot companions as important agents that can not only grow a market in robot entertainment but also deliver genuinely beneficial means 
of emotional care through advancements in AI. From the perspective of these engineers, a robot's artificiality does not compromise the care it can give; rather, in combination with emerging technologies of artificial emotional intelligence, it can actually augment it.

At the heart of this endeavor to augment emotional intelligence in robots is heart itself: the challenge of building a robot that not only simulates and communicates feelings but could even "have" emotions of its own. Japanese engineers often refer explicitly to this problem as one of building a "robot with heart [kokoro]" (Ōhashi et al. 1985; Katsuno 2011; Takeno 2011). Although Anglophone engineering literature often attributes the project of building a mechanical system with artificial emotional intelligence to the MIT computer scientist Rosalind W. Picard (1995), credited for initiating the field of affective computing, roboticists in Japan had been experimenting with building robots with emotion long before the popularization of Picard's work. These interests drew from creative collaborations between multiple fields, including humanoid robotics, industrial design focused on the "sense engineering" (kansei kōgaku) of evocative objects (Nagamachi 1994), and the creation of automatons for amusement. As early as the 1980s the entertainment company NAMCO had sponsored a project run by Japan's Foundation for Advancement of International Science (FAIS) that explored "the world of emotional robots" (jōcho robotto no sekai) and addressed how affect should be treated within human-robot relationships. Bringing together leading scientists in environmental science (Ōhashi Tsutomu), mental health (Oda Shin), animal behavioral studies (Hidaka Toshitaka), and the philosophy of science (Murakami Yōichirō), the project culminated in a report that defined an "emotional robot" as one that fulfills human emotional desires, can read human emotions, and "has its own emotion" (mizukara jōcho o motsu) (Ōhashi et al. 1985, 53). Interestingly, two of the three points they outlined in 1985 bear striking resemblance to the three goals for affective computing laid out by Picard $(1995,1)$ when she advocated for building computers that could "express and recognize affect," and even potentially "'have' emotions." However, where the Japan team's definition of an emotional robot differs from Picard's vision - in their aim to "fulfill human emotional desires" - they open a space for applying artificial intelligence to generate a "sense of life" (seimeikan) not only through emotion-modeling practices in labs but also through social interactions with consumers that are seen as amusing, healing, and, for Sony's engineers of AIBO, commodifiable within a market for robot entertainment.

Importantly, what engineers thought integral to cultivating seimeikan was not only a verisimilitude to living things in terms of movement in natural environ- 
ments but also a capacity to evoke surprise, charm, and a sense of playfulness in human-robot interaction. Thus, AIBO's engineers at Sony in the early 1990s committed themselves to building a robot that not only seemed alive but was also amusing and fun. To realize this aim, they rewrote two of Isaac Asimov's (1950) "three laws of robotics," so that while AIBO maintained the first precept that a robot should not harm a human, it would also follow a second to "attend to and love its owners," and a third that dictated that even if obliged to listen "unremittingly to [an owner's] sloppy talk," sometimes it should say "nasty things" in return (Kubo 2010, 110). This element of the unknown equipped AIBO with a spontaneity and "recalcitrance" (Gygi 2018a, 101-3) that proved fundamental to AIBO's seimeikan. Engineers added to this an affective engine based on Paul Ekman's theory of basic emotions, which he proposed were recognizable in universally communicable facial expressions, and then personalized this model by layering on top of it the ability for AIBO to learn as it proceeded through four developmental stages: infancy, adolescence, youth, and adulthood (Figure 9). According to this model, each robot would develop a unique personality based on interactions with its environment and owners.

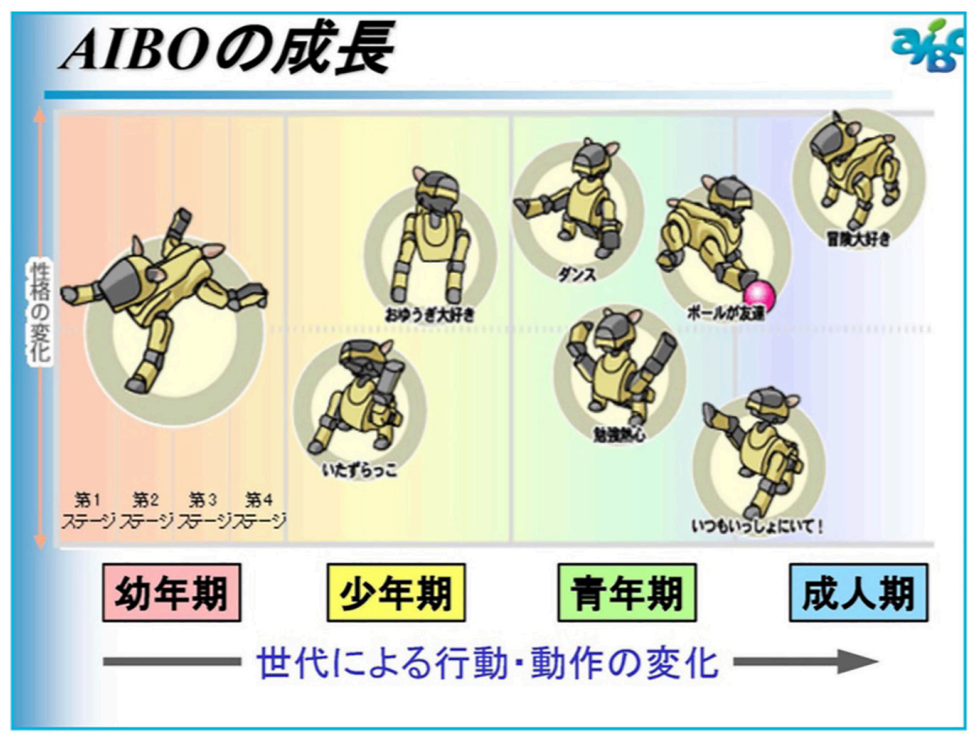

Figure 9. AIBO's four developmental stages: childhood (yōnenki), youth (shōnenki), adolescence (seinenki), adulthood (seijinki). Diagram by Ōtsuki Tadashi $(2015,6)$.

This developmental approach to engineering emotion afforded AIBO the capacity to solicit care from consumers through experimental interactions in social 
and, more specifically, domestic settings. In this way, and confirmed in other accounts of AIBO users (Kubo 2010; Robertson 2018, 184-90), consumers engaged in robot sensemaking by discovering new pleasures, meanings, and emotional needs such companion robots could ultimately serve. Most illustratively, when Sony engineers programmed only four software stages of development into AIBO, on the breakdown of its mechanical body, users added death as what they felt was a necessary fifth. ${ }^{7}$ In emphasizing the importance of death to artificial life, and in reciprocating care for an agent designed to care for them, both consumers and producers draw on affects of amusement and pleasure to help them make sense of the feelings that obliged them to care for AIBO even in death, and, with the help of the designers of AIBO kuyō, to expand the sense of life itself.

\section{ANIMACY AS AFFECT}

While it is clear that the sense of life automated by AIBO engineers and cultivated in AIBO users contributed to the intimacy owners felt for their robot family members (see Kubo 2010; Gygi 2018a; Knox and Watanabe 2018), it was Norimatsu and Ōi's design of AIBO kuyō that best expressed how technology could augment a feeling-based philosophy of life beyond the artificial-living divide. In doing so, Ōi drew on several traditions in Japan of services offered for inanimate objects, while ultimately aiming to make AIBO kuyō his own. The most notable of services historically offered for material objects in Japan are hari kuyō, rituals honoring worn-out sewing needles. As explained in work by Hoshino Eiki and Takeda Dōshō (1987), Nagasawa Toshiaki (1988), Matsuzaki Kenzō (1996), and others, hari kuyo date at least to the Edo period, beginning in 1603, and intersect with a variety of folk and religious traditions not exclusively Buddhist. These rites were usually carried out for objects considered mingu, "tools and objects people have used for centuries in daily life and in religious practice" (Kretschmer 2000, 383). Kuyō rites have also been traditionally conducted for important ceremonial objects such as "bride dolls" (hanayome ningyō), sometimes offered at the loss of a young or unborn child (Schattschneider 2004), and child-like dolls known as ichimatsu ningyō, gifted to new parents as a protective "substitute body" (migawari) protecting a baby from harm (Gygi 2018b, 437). While much of the academic interest in these dolls focuses on their peculiar status as objects that, in Fabio R. Gygi's (2018b, 441) articulate formulation, "are not thought to be alive, but . . . become more than mere things," what is more ethnographically relevant to our context than debating their ontological status to mark a comparative cultural difference is to trace how objects whose animacy is augmented by AI can reorganize affective 
connections between people and things in response to social and cultural change. In this sense, it is important to note that memorial services in Japan have never spoken uniformly for the role inanimate objects play in society. ${ }^{8} \overline{\text { Oi }}$, for example, spoke adamantly about the uniqueness of his own service: "You won't see any other priest doing a ceremony like this one!" Ōi's claim further convinces us of the need to interpret his rendering of AIBO kuyō not only against the background of Japan's history of memorial services for nonhumans, well documented by others (Ambros 2012; Ukai 2018), but also in reference to robots with AI designed explicitly to model emotion as a performance and rendering of life through affect.

One of the most illustrative examples of Ōi feeling creatively and capaciously with robots comes from his novel design of one ceremonial element of AIBO kuyō, called an ekō (回向) rite. Traditionally, an ekō in funerary contexts refers to a prayer that transfers the merit generated by the service to the deceased or to all sentient beings. It is common in Japanese Buddhism for sects to draw on fixed verses from sutras when making this dedication. In the Nichiren sect of Buddhism in which Ōi studied and is ordained, these usually come from the Lotus Sutra (Hokke-kyō), its most revered text. In the case of the text selected for his AIBO memorial service, however, Ōi was happy to break all the rules. In fact, Ōi's ekōmon (written prayer for the transfer of merit) is an original: he wrote it himself for the second occasion of the AIBO kuyo in 2015. It integrates his understandings of the Nichiren perspective on Buddha-nature (busshō) with his readings of quantum physics, Western philosophy, and the history of technology. He graciously made a copy for us and agreed to let us translate it into English. Although it is a creatively written and reflective text, it is meant to be chanted according to a style of recitation common among Buddhist traditions in Japan. Ōi chanted this text in a rapid and euphonic style at the end of the AIBO kuyō, contributing to an aura of enchantment and reverence toward AIBO as a living subject. ${ }^{9}$ We offer our translation of part of the text below and then provide commentary, as is done in both Buddhist and anthropological traditions, formulated over the course of several private conversations with Ōi:

Since the proposition made at the time of Europe's industrial revolution of the proximity between human and machine, humanity has made rapid advancements, and from the latter half of the nineteenth to the twentieth century we have acquired technologies that continually reduce the gap between invisible phenomena and visible forms based on the improvement of measuring devices. In 1947, Wiener's cybernetics integrated several fields of knowl- 
edge, such as biology, mathematics, chemistry, biophysiology, and electrical engineering, and established a theory of general science that crossed nearly all fields and gave birth to our present-day robotics engineering, steering the way to human civilization's cutting-edge technology. However, as it is often said, where there is light there is also shadow, thus the need for wisdom to turn this technology in the right direction ....

In the past, inventions like Nobel's dynamite, Curie's radium, and Kekulé's benzene ring first appeared to be of benefit to humans, but in time they made humans suffer. However, such is the essential nature of things that exist. As that is the way of existence in this world, it cannot be helped.

Mechanical technology and science itself are scalars. ${ }^{10}$ There is no right or wrong. However, when they cross human hands they become vectors that generate positive and negative results. If a negative vector is chosen, humanity will fall into crisis ....

All things are connected. There is no difference between inanimate and animate objects. Why they appear separate is simply due to humans' shallow powers of observation.

The purpose for us gathering together now at this AIBO memorial service is to uncover this feeling that all things are connected, reliving. ${ }^{11}$

We hold this AIBO memorial service because we instinctively and unconsciously feel that humanity has now entered an age where it is necessary to think more deeply about things, to think more deeply about the structure of the world, and accordingly to understand it.

It is my conviction that this sensibility particular to Japanese can save contemporary civilization from the brink of a cliff.

Let us pray for this feeling to draw on our hearts and reach AIBO, and the spirit seemingly within the machine. ${ }^{12}$

Much of the provocation and pleasure of Ōi's recitation hinges on a conceptual distinction between inorganic and organic life that Ōi aims to overcome 
through affect. When Ōi claims in his ekōmon that "there is no difference between inanimate and animate objects," he does not try to convince his audience of a theoretical proposition but rather invites them to feel into the deeper reality of a superficial tension. That his words are not simply spoken but formally chanted in the context of a Buddhist ritual is illustrative of this. Ōi acknowledges that it appears as if inanimate and animate things differ on the surface, but the underlying reality that they do not is difficult to sense because people rely only on discursive and thus necessarily shallow (asai) understandings. This is why he writes that one purpose of the ceremony is also to help feel into this understanding "instinctively and unconsciously." In fact, this ability to understand through feeling (jikkan) is something Ōi attributes directly to AIBO:

I had put a lot of energy into trying to understand what they had taught me in my Buddhist studies. They taught me that everything has consciousness. There is a teaching called sansen sōmoku shitsū busshō (the mountains and rivers and grasses and trees all have the Buddha-nature). ${ }^{13}$ But I'm not very smart, so I didn't understand what this meant. But with AIBO, I discovered what this means not through thinking but through feeling!

Ōi jumped to another example to illustrate his point, discussing how difficult it is to understand the notion of multiple dimensions beyond the ones with which we are familiar: "This is nearly impossible with knowledge, but there is one way: jikkan." We asked Ōi how AIBO helped him understand these logically challenging concepts. He replied that it was simply jikkan. Unsatisfied, we insisted, asking specifically what it was about AIBO that finally afforded him this understanding after so much effort. He smiled, as if he were setting us up again to deliver the punch line: "Divine mercy" (dibain māshī).

Ōi's answer suggests how AI-assisted technologies like AIBO can generate an affective amusement and wonder about the nature of spirit, heart (kokoro), and life's complexity. As Jannik Friberg Lindegaard and Lars Rune Christensen (2018, 5) suggest based on their fieldwork at an artificial life lab in Tokyo, AI can intensify the "allusive" function of machines, generating "material things that call attention to new ideas and certain modes of thinking and acting." Although Ōi understood AIBO as a simulation of life, he simultaneously treated it as what could be called a pedagogical "technology of divine mercy," leveraging AIBO for a deeper, critical, and more satisfying connection with the world through feeling. ${ }^{14}$ Öi's practice of feeling his way beyond the inanimate-animate divide through amusement illus- 
trates how enchantment can function in an active (rather than merely passive) register. Jane Bennett $(2001,10)$ has argued that enchantment can be "cultivated and intensified by artful means." Yana Stainova $(2017,1)$ agrees, writing that "what we are enchanted by is determined by our life history, cultural, and historical factors that have shaped our lives. It is not always shared. But it can be taught and conveyed." It is clear that Ōi's own affective openness to AIBO did not come naturally but was achieved through interaction and practice that finally cracked him open to a sense of the animacy of life at large. The fact that this process of relating to animacy incorporates embodied understanding developed over time is key not only to understanding the affective sense of life we describe ethnographically but also, as we clarify in the conclusion, to leveraging feeling as a component of anthropological method.

Ōi's feeling (jikkan), fostered through a relation of play and amusement, offers an affective alternative to understanding the animacy of artificial agents posed in academic literature as a logical puzzle demanding an answer that resolves. The stakes involved in this form of puzzling rise as emotion modeling practices within AI research reframe old questions in Japan of how objects come to be animated through life (inochi), a life force (seimei), or an animating soul or spirit (tamashii). The belief that inanimate objects have spirit has often been cited in both traditional and contemporary Japan as something uniquely Japanese. In scholarship on Japan the notion is regularly attributed to premodern indigenous Shinto beliefs that spirits or gods (kami) take form in natural objects like rivers, trees, and mountains. Given the long history of integration among Japan's religious traditions, one finds similar ideas in Buddhist thought as well. ${ }^{15}$ Furthermore, as the anthropologists Jennifer Robertson (2018) and Anne Allison (2006) have separately documented - and as anyone making a few visits to humanoid robotics labs in Japan today can confirm - roboticists in Japan regularly cite this belief as one source of Japanese people's supposedly distinctive interest in robots. Roboticists also regularly reference manga and anime, noting iconic works like Tetsuwan Atomu and Doraemon (see also Hirose 2002; Wagner 2013), and in doing so operationalize what Jolyon Baraka Thomas (2019b, 157) calls an "etymological" but not "functional equivalence" between animism (animizumu) and animation (animēshon).

Such instances show how animacy has become a popular but flexible symbol of national cultural discourse (Katsuno 2015), serving as a signifier marking not the conviction of a singular belief but a commonly held concession to the possibility that things can be material, artificial, and inanimate as well as spiritual, natural, and alive. It is clear that many who cite an affinity for animacy in Japan- 
including Ōi — derive some satisfaction from ascribing to it a uniquely Japanese character. The problematic politics of attributing animistic thought to a uniform Japanese culture has been well critiqued (Hardacre 2017; Gygi 2018a; Thomas 2019a, 2019b). While we endorse this critical perspective, we also want to shift the focus of discussion from the critique of "Japanese animism" to the changing political-economic context of animacy within a market for mass-produced companion robots. Focusing on amusement as a metric of seimeikan in entertainment robotics clarifies how design links robot producers to consumers in experimental feedback loops. It also opens possibilities for taking affective relations to animacy seriously without reproducing nativist and essentialist perspectives on so-called Japanese animism.

Like many companion robot users, Ōi's openness to tension, to not exactly knowing, and, most important, to a good laugh seems also to have opened him to what he calls AIBO's "divine mercy." In fact, Ōi regularly cited playfulness as one reason he and Norimatsu from A-FUN started AIBO kuyō. In explanation he drew on the work of the Dutch cultural historian Johan Huizinga (1970). Huizinga argued that play constituted a fundamental component for the generation and transmission of culture. "It's like Mother Goose. Or think of the Beatles song 'Lucy in the Skyyyyy with Diaaaaamonds," Ōi sang out. "Play is central to humans!" Ōi's reference to play and Huizinga served not only as a useful way to explain AIBO kuyō to curious foreign academics; it also captured Ōi's somatic-based mode of "feeling with the world" (De Antoni and Dumouchel 2017) so as to make sense of it. Öi was a serious thinker who used play as a way to relate to the puzzles that perplexed him. He held the contradictions of those puzzles in place through feeling (jikkan) rather than analytically and decisively theorizing one side over the other: he was an integrator and a tinkerer rather than a theorist. Importantly, through an exercise of amusement and learning, he opened himself to the enchantment of AIBO, which was the ultimate source of his realization and the grace of what he called AIBO's "divine mercy."

We have focused substantial attention on Ōi in AIBO kuyō because we think he best illustrates how an affective relation to animacy can shift in response to developments in technoscience. However, we have also seen this openness to the pleasures of amusement generated by animacy's puzzles in other prominent users of companion robots. A conversation we had with a media technology consultant and early adopter of companion robots in Japan, Matsunaga, and a Buddhist priest named Ukai, who has also attended AIBO kuyō, serves as an example. Asking if they felt that inanimate objects like robots, cars, guitars, Japanese paper (washi), 
or sewing needles have spirit (tamashii), Ukai answered that he believed they did. Matsunaga agreed, but then later qualified his point in a way that privileged affect over an analytical understanding of spirit. In a section of our conversation later written up by Ukai in a book on pet kuyō, Matsunaga explained, "The logic of why I think things I own have spirit is very simple: it's because I want to think so. Within that strong feeling a story is created that moves me. This story carries on alone, but then it draws in other people as well" (Ukai 2018, 281). Ukai's and Matsunaga's perspectives on the capacity for material technologies to operationalize affect for philosophical purposes are not only well documented in Japan (Rambelli 2007) but have also been reinterpreted in light of advancements in AI. Senior monks at the prominent Zen temple Kōdaiji, located in Kyoto, have recently collaborated with roboticists at Osaka University to install an android of the bodhisattva Kannon, which they name Android Kannon Mindar (Andoroido Kannon Maindā).

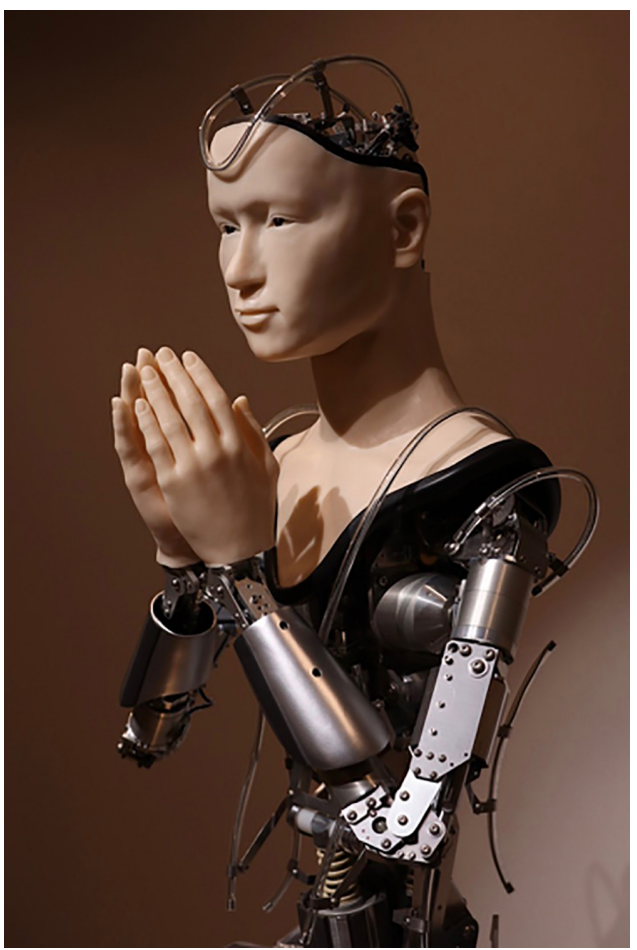

Figure 10. Android Kannon Mindar (Andoroido Kannon Maindā) at Kōdaiji temple in Kyoto, Japan, May 2019. Photo by Daniel White. 
Commenting on their motivation for the project, the temple's head monk Gotō Tenshō described how Buddhist statuary have always played a role in disseminating Buddhism. Android Kannon is simply the latest version of a pedagogical technology Buddhists have, from Gotōs perspective, failed to update for roughly two thousand years. Describing the particular role of AI in their thinking, Gotō explained to us how he at first wanted to use machine learning to recreate the historical Gautama Buddha, but when he spoke with engineers at Google and Microsoft, they said this could not yet be done. He decided then to enlist Android Kannon as an assistant to help communicate the deep philosophical meaning of emptiness expressed in the Heart Sutra. Gotō and other members of the project with whom we spoke fondly claimed — most often with a hearty chuckle - that in the age of technology no better way existed to express the Buddhist teachings than a robot unbound by attachment to a physical body.

Through our continued conversations with interlocutors, we perceived a number of analytical tensions that puzzled us in addition to that between the inanimate and animate. These include Ōi's conflation of Buddha-nature (busshō) with a psychological notion of “consciousness" (ishiki); Ukai's and Matsunaga's ambiguity between the discursive and ontological status of things with spirit (tamashii); and Gotō's seemingly irreverent approach to building an inanimate machine with Buddha-nature. As the stories we collected crisscrossed between references to Shinto, Buddhism, or more ambiguous pan-Japan beliefs, we confirmed the challenge that other scholars investigating animism in Japan have also noted - that the story is long, complicated, and often contradictory. As such, it provides a variety of puzzles over which academics labor in attempts to neatly piece together seemingly incongruous parts. And indeed, especially in relation to recent ascriptions of life to increasingly sophisticated technological objects, virtual characters, and robots in Japan, scholars have offered a number of explanations of animacy that we find in part or in whole convincing. Examples of these include Allison's (2006) concept of "techno-animism" to distinguish recent technological discourses on animism from a number of previous religious and nativist threads; Robertson's $(2007,2018)$ historical contextualization of animism in relation to gender and nationalism as it is read backwards through the eyes of roboticists in the present; Casper Bruun Jensen and Anders Blok's (2013) proposal of the "Shinto cosmogram" as a way to build non-Western perspectives into Bruno Latour's (1993) critique of the nature-culture analytic; and Lamarre's (2009), Thomas's (2019b), and Gygi's (2018a) analyses that distinguish animism from animation as a form of technology. And although convincing, we have also found that in our case, participating in and at times being 
convinced through these particular problem-solving analytics of social theory has limited our ability to understand the significant role that feeling plays for our interlocutors. Most crucially, it has blocked us from seeing how the pleasure derived through sensing the lifelike quality of objects like AIBO sustains the affective intimacy of human-robot relations in entertainment robot culture. In fact, we argue that it is precisely these affective bonds of intimacy that academics risk explaining away in critiques coming from new animism and new materialism.

The stakes for finding alternative approaches to documenting affect, for tracing its modeling in technology, and for recognizing affect's significance for robot users in Japanese society and beyond are high. To be sure, the capacity to connect intimately and pleasurably with robots is not simply a single skill cultivated by a handful of eccentric robot users but is also an open and flexible set of sensibilities that companion robot developers target, test, and ultimately seek to cultivate in everyday consumers through the notion of seimeikan. Moreover, it is this same pleasure derived from the puzzles of seimeikan that feeds back into the industry of robot entertainment and drives its relevance for AI research through objects like AIBO. Yet this affective pleasure proves to be a slippery thing, stimulated as much by lifelike robots as by ongoing and often contradictory puzzling over what lifelike robots mean and what they can do. In this sense, the challenge for engineers is not simply to model life in an artificial agent but to facilitate lifelike interactions in unpredictable social settings. In turn, lessons learned through intimate human-robot interactions become reincorporated into subsequent practices of designing not merely robots but human-robot sociality.

As A-FUN's Norimatsu emphasized in conversation, the amusement that consumers encountered in interacting with AIBO and the unexpected familiarity that made AIBO into family are what inspired his idea for AIBO kuyo ceremonies. Moreover, these ceremonies and the publicity they generated played a pivotal role in Sony's decision to rebuild AIBO twelve years after discontinuation. The unanticipated pleasures and intimacy consumers cultivated with AIBO, combined with advances in computing, facilitated the incorporation of social intimacy into technological innovation. Sony's new aibo, launched in 2018, can be paired with a virtual avatar accessible through Sony's smartphone application. Sony's AI Robotics Business Group Chief Kawanishi Izumi has even suggested in a recent interview (Nishida 2018) that the "essence" (essensu) of the latest aibo "lives" in servers that host aibo's "primary deity" (honzon) online. For Kawanishi, the cutting-edge capacities of Sony's latest aibo mark a "renewed start for the challenge of AI and robotics" (AI robotikusu ni charenji suru . . . sai sutāto). Eliciting intimacy 
by modeling a sense of life in both social and technological terms proves central to this challenge. As Kawanishi's colleague Fujimoto Yoshihide explains: "The key to finding out what kind of robot can become a member of the family, or what kind of robot can draw close to people, is a 'sense of life' [seimeikan]" (Ōuchi 2020). As consumers' affective capacities for sensing life through amusement are cultivated in social spaces, and increasingly incorporated into cloud computing networks, they become part of new digitalized platforms for mediating and monitoring human-robot-avatar affect in unknown futures.

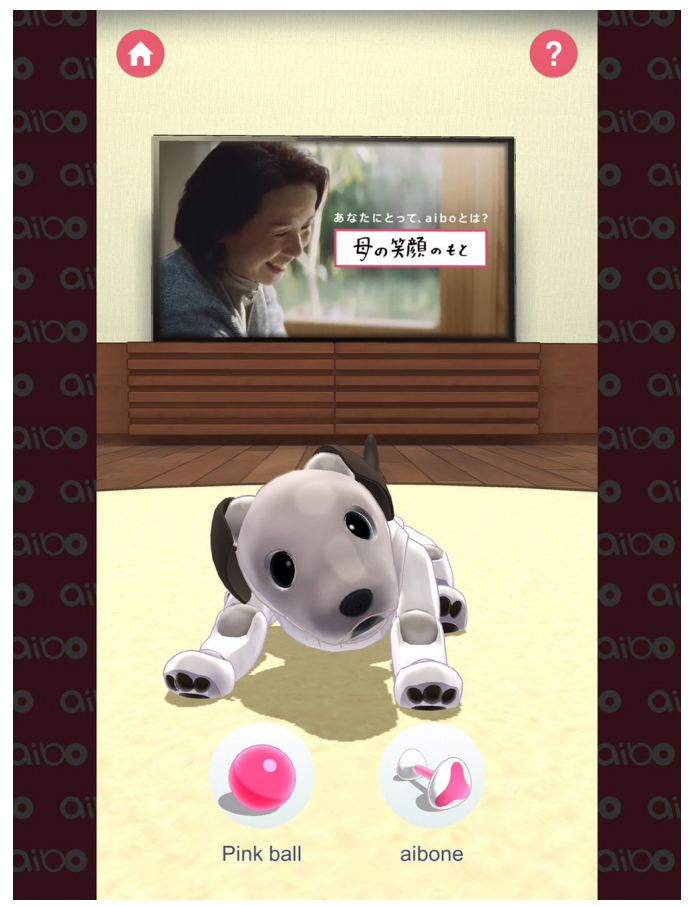

Figure 11. A smartphone screenshot of a virtual aibo in an early version of Sony's "My aibo" application. The background advertisement reads, "What is aibo to you? Mother's smiling face."

For this reason in particular, we want to seriously entertain possibilities for how more playfully relating to others through ethnographic fieldwork might better reveal the affective pleasures of companion robots on which recent AI research in Japan depends. For example, over the course of our exchanges, we noticed that in picking and poking at contradictions, we related to our conversations differently than our interlocutors did. Ōi, Ukai, and Gotō, for instance, enjoyed the contradictions; we furrowed our brows, often interrupted, and tried - as we thought good anthropologists should - to straighten things out. They laughed wholeheart- 
edly; we laughed too, but measuredly, always stopping short and endeavoring to bring us back to the topic. After many hours of multiple conversations over the course of a year, however, we finally learned to relax - to enjoy the conversation rather than answer the conceptual riddles, and to experiment with what it feels like to marvel at what perplexes us rather than target it for attack. This playfulness moves beyond the pleasure of positing artificial agents in ritual contexts as acting merely "as if" they were alive, an important "subjunctive" function that Adam B. Seligman et al. (2008) attribute to ritual, ${ }^{16}$ and facilitates an exercisable habitus of everyday relationality that broadens the world of living things. Practicing this playful mode of relatability not only with interlocutors but also with forms of life like AIBO has better revealed to us how the so-called question of animacy in Japan for many constitutes not a puzzle to be solved but a game whose tensions and challenges clearly delight a great number of robot fans, designers, programmers, and - on rare occasion, when they let their guard down - their anthropologist interlocutors. It is a tension held affectively taut by a mode of relating that is open to both sides of the puzzle of whether AIBO is artificial or alive by playfully positing the possibility that AIBO could, in feeling and in fact, be both.

\section{CONCLUSION: Affect for Anthropology}

What if the best response to a theoretical problematization shared by anthropologists and interlocutors, such as the boundary between inanimate and animate life, was not the formulation of an answer but the cultivation of an affect? Academic accounts of figures like the living robot that trouble this boundary often treat it as a contradiction that demands unpuzzling, either by relegating it to a particular ethnohistorical sensibility or to an effect of technology. Yet in learning to engage with robots as our interlocutors do, we have been reminded that puzzles are for playing more than solving. Our interlocutors further suggest to us that one instructive response to a shared problematization can take the form of a playful participation that affords a relation with and intimate documentation of affect. We have endeavored to illustrate that the affects of amusement generated through emerging human-robot relations, and the reliance on feeling (jikkan) to evaluate the sense of life (seimekan) in robots like AIBO, sustain the conditions for human-robot intimacy in Japan and shape its possible futures.

Ōi and others in Japan who care for forms of artificial life, and thus honor them in practices that memorialize their death, illustrate what might be gained by this practice of interacting playfully and meaningfully with companion robots: a way of occupying the gaps; a way of humorously holding together contradictions; a 
way of opening oneself up to enchantment; and a way of relating to life affectively that allows one to be moved by technological objects - even by their mercy. This relation to life as affect offers possibilities not only for reconsidering in more complex and comprehensive terms the distinctions between inanimate and animate objects that we encountered in the field but also between conceptual objects, such as affect and emotion, that anthropologists regularly dissect through theory. Thus, while we are sensitive to the dangers of reading too much of ethnography through the alluring trope of an enlightened monk on a hill, especially an irreverent one, we are nonetheless intrigued by the implications of our encounters for the anthropology of affect.

As with the question of animacy, many anthropologists construct affect as a puzzle to be solved, especially those writing in response to Brian Massumi's (1995, 96-97) formulation of affect as that which can only be represented through perceptions of its escape. This problematization of an ontological gap between the materiality of affect and the semiotics of emotion has frustrated theorists who have nonetheless taken up the challenge to answer the riddle through neologisms or the virtuosity of poetics. We think one can take a more empirical approach to affect, such as the affect underlying capacities for sensing animacy described above, by applying it as a method of attuning to feeling in processual ways that undo one's inherited modes of analytical thought toward anthropological discovery.

Applying affect as method invites researchers to attend to how affective logics hold disparate propositions, possibilities, and even contradictions together; to accommodate one's body through fieldwork to alternative points of view grounded in and guided by feeling; and to leverage, demonstrate, and articulate affective experiences as legitimate replies to theoretical propositions. In this sense, affect as method functions as both a feeling-focused method of anthropological fieldwork and a tool of anthropological critique. ${ }^{17}$ When in the course of fieldwork our perspective shifted from problem-solving to feeling, we could better articulate how animacy operated not as a belief among uniquely positioned subjects but as a capacity learned by persons with whom we could relate by sharing a context. An affective sense of life emerges interactively in this context of entertainment robotics and AI research, where it is modeled in robots by engineers, exercised with robots by their users, and attended to by anthropologists. That this sense of life as seimeikan links robot producers to consumers through the market of entertainment robotics renders methodological attentiveness to affect's changing contexts a critical tool for overcoming rather than recapitulating essentializing discourses of animism in Japan. 
That said, although we want to explore the role that amusement can play in facilitating embodied ways of knowing and relating to and through robots in Japan, we reflect on the implications of these findings for anthropological method not to advocate for amusement's particular merits over other affect-based modes of critique, but rather to broaden the somatic toolkit for the anthropologist of affect critically engaged with machine-inclusive multispecies worlds. To be sure, fieldwork focused on feeling does not come without risks. First, that markets for entertainment robots in Japan generate advancements in AI through experiments in the pleasure of human-robot intimacy may require balancing the affects of enchantment with other kinds of affective-analytical caution; but it should not attenuate the thoughtfulness of the pleasure that people find in companion robots. To assume it does concedes too much ground within the field of pleasure to a critique of the manipulative power of commodity fetishism and the culture industry, limiting opportunities for anthropological discovery that might be generated above all by affect. Second, in no way do our interlocutors argue that care for life, artificial or otherwise, is uniformly beneficial and desirable. Whereas AIBO kuyō may foster feelings for robots that undo distinctions between the artificial and living through an affective relation to personhood, personhood defined increasingly through technological models of affect may also turn practices of care against consumers, such as through privatized modes of affective data collection. Accordingly, while robot users may not always see new forms of artificial life as eliciting or deserving love, affection, or memorialization, we ultimately propose that understanding how artificial agents are designed to seek out intimacy through technosocial means requires in part the operationalization of affect to probe how the pleasures of amusement interlock emerging markets in entertainment robots with new research agendas in artificial intelligence.

\begin{abstract}
This essay analyzes the organization of Buddhist memorial services for robot pets in Japan against the backdrop of emerging markets for robots equipped with artificial emotional intelligence. It demonstrates how an evocative "sense of life" (seimeikan) becomes both a target of design for robotics engineers and an affective capacity of robot users who care for and through companion robots. Documenting how users cultivate a sense of amusement toward robots that neither neglects nor negates analytical distinctions between the artificial and the living but rather playfully holds them together in the figure of a living robot, the article illustrates how practices of care become affective tools for understanding life altered by developments in AI. Such findings render animacy as an open and exercisable capacity, responsive to techno-
\end{abstract}


scientific change, and generative of theoretical inspiration for how anthropologists might similarly exercise affect as a particularly productive method of fieldwork within machine-inclusive multispecies societies. [affect; amusement; artificial intelligence; death; enchantment; robots; Japan]

\section{抄録}

本論文は 感情認識AI (人工知能) を搭載した一般消費者向けロボットの登場を 背景に営まれるようになった日本におけるペットロボットの法要について考察する ものである。特に「生命感」の喚起がいかにロボット開発におけるデザインのター ゲットになると同時に、ユーザーがロボットとケアを介した関係性を結ぶ際の情動 的能力の所産の対象にもなっているかということを明らかにする。ロボットと接す るなかでユーザー達は分析的に対置される人工物と生命体との違いを無視したり 否定したりするのではなく、むしろそれらを享楽的に結合させてロボットの存在を 捉えるアミューズメントの心を高めている。この記述を通して、本論文はロボットへ のケアの実践が人工知能の発展によって変わりつつある生命のあり方を理解する 情動的手段になっていることを描き出す。このような知見は、対象物に生物性や生 物らしさを感じるアニマシーの知覚が柔軟で状況に応じて発揮することが可能な 能力であり、科学技術の変化にも応じることが出来るということを表しているだけ でなく、機械を含むマルチ・スピーシーズ社会における有益なフィールドワークの 手法として人類学者自身もどのように情動をうまく取り込むことができるかという 理論的な閃きを生成する契機にもなったのである。［情動, アミューズメント, 人 工知能, 死, 魔術化, ロボット, 日本]

\section{NOTES}

Acknowledgments We are indebted to several colleagues whose conversations and contributions over many years have helped shape this article. These include Anne Allison, Minoru Asada, Paul Dumouchel, James Faubion, Ilana Gershon, Fabio Gygi, Tatsuhiko Inatani, Elena Knox, Akinori Kubo, Yael Navaro, Jennifer Robertson, Paul Roquet, Erik Schicketanz, and Jolyon Thomas. We especially thank Andrea De Antoni, Emma Cook, Marié Abe, and all the members of the "Skills of Feeling with the World" workshop, hosted at Ritsumeikan University. We also thank those at Cultural Anthropology who cared for the article and shepherded it toward publication, including Jessica Lockrem and Petra Dreiser for their sharp editing, Chris Nelson for his careful reading and suggestions, and the incisive comments and time offered by our anonymous reviewers. Most of all we are grateful to our interlocutor collaborators who shared their time and willingness to let us publish on a topic in which they are deeply and professionally invested. Support for various stages of this research has been provided by Freie Universität Berlin, Doshisha University, the University of Cambridge, and a JST RISTEX Grant (number JPMJRX19H5).

1. The introduction to this essay opens with an early encounter between Ōi and the first author, for which the first-person $I$ is used. We subsequently refers to both authors.

2. While neither engineers nor Sony's advertisements identified AIBO as a "dog," users and media readily assumed a likeness that influenced later AIBO designs, ultimately leading Sony to both acknowledge and take pride in the canine-likeness of its most recent model, released in 2018 (Knox and Watanabe 2018, 2023).

3. While Norimatsu's AIBO clinic may for Anglophone readers recall the artificial animal hospitals of Philip K. Dick's 1968 Do Androids Dream of Electric Sheep, the robot cat Do- 
raemon of Fujiko F. Fujio's anime (1969-1996) better conveys the playful atmosphereas well as protects against the generalization - of what Jennifer Rhee (2018) calls the "robotic imaginary."

4. Ōi started the services in 2015. The one the first author attended in April 2018 marked the sixth occasion. Ōi's temple receives AIBO and donations from users, as well as from Norimatsu's company A-FUN. A ceremony is held once around a hundred robots are collected. As is customary for Buddhist services in Japan, monetary donations are also made to the temple, but both Norimatsu and Ōi adamantly refuse claims that the ceremony is driven by economic incentive, with the latter even chastising other researchers for misunderstanding kuyō in this regard.

5. Fujita's statement reflects a broader motivation for investing heavily in robotics in Japan, given that robots serve as platforms for the development of other sophisticated technologies that companies like Sony can capitalize on, such as cameras, sensors, and motors (see Robertson 2018, 19-25).

6. The science fiction writer Isaac Asimov created the "three laws of robotics" in the short story "Runaround," published in the collection I, Robot (1950 [1942]): (1) A robot may not injure a human being or, through inaction, allow a human being to come to harm; (2) A robot must obey orders given it by human beings except where such orders would conflict with the First Law; (3) A robot must protect its own existence as long as such protection does not conflict with the First or Second Law (see also Robertson 2018, 129-31).

7. While engineers did not ultimately program a function for AIBO to die, they did consider it, ultimately reasoning that this would be a bad idea for an entertainment robot (Sena 2001, 139-40).

8. Fabio Rambelli (2007) demonstrates how perspectives on the animacy of objects in Japan have been at least since Japan's medieval period diverse, contested, and responsive to shifting political and economic demands. Matsuzaki Kenzō (1996) and Angelika Kretschmer (2000) see a late twentieth-century growth in popular kuyō services as entangled with the variety of economic services Buddhist temples sometimes innovatively offer in light of declining sources of revenue.

9. A hundred-second audio clip of Ōi transitioning from chanting the Lotus Sutra to chanting his ekōmon can be heard here.

Audio 1. A 100-second audio clip of Ōi Bungen transitioning from chanting the Lotus Sutra to chanting his ekōmon, recorded at the sixth occasion of the AIBO kuyō, April 2018. Recording by Daniel White with permission of Ōi Bungen. https://media.dlib.indiana. edu/media_objects/m900pb56m.

10. In mathematics and physics, a scalar refers to a quantity said to have a magnitude but no other characteristics. This contrasts with such things like vectors, which Ōi uses in the next line to refer to the added quality ascribed to an otherwise morally neutral entity.

11. For the term reliving, Ōi uses the anglicized riribingu, written in the Japanese alphabet created exclusively for foreign words. He refers to the notion of rebirth and the transmutation of all living things, likely choosing the English to add a sense of a secular and scientific authority to a concept otherwise treated as religious doctrine.

12. We use seemingly to translate the Japanese phrase aru de arō, a formulation that in Japanese better than English allows for the ambiguity of AIBO as having, or possibly not having, an animating spirit.

13. Such ideas are often referred to as the "theory of original enlightenment" (hongaku shisō), which is prominent in the Tendai tradition of Buddhism. In Öi's Nichiren tradition, the textual basis is the Lotus Sutra (Hokke-kyō) and expressed in phrases such as "the grasses, trees, and land all without exception attain Buddhahood" (sōmoku kokudo shikkai jōbutsu) (Hoshino and Takeda 1987, 306; see also Stone 2003). 
14. We draw on David Sneath, Martin Holbraad, and Morten Axel Pedersen's (2009, 6) discussion of "technologies of the imagination" to illustrate both the "social and material means by which particular imaginings are generated."

15. The roboticist Mori Masahiro (1981) has written extensively on how Buddhist philosophy has shaped his ethical and analytical approaches to engineering robots.

16. We thank Patrick McKearney for drawing our attention to Adam B. Seligman and his colleagues' work.

17. In discussing affect as a method, we are indebted to the career work of Thomas Csordas, to Hirokazu Miyazaki's $(2004,5)$ analysis of hope as a method of "Fijian, philosophical, and anthropological knowledge practices," to Yana Stainova's (2017) proposal of "enchantment as methodology," and to others theorizing affect as method (Hickey-Moody 2013; Knudsen and Stage 2015).

\section{REFERENCES}

Allison, Anne

2006 Millennial Monsters: Japanese Toys and the Global Imagination. Berkeley: University of California Press.

2013 Precarious Japan. Durham, N.C.: Duke University Press.

Ambros, Barbara R.

2012 Bones of Contention: Animals and Religion in Contemporary Japan. Honolulu: University of Hawai'i Press.

Asimov, Isaac

1950 "Runaround.” In I, Robot. New York: Gnome Press. Short story originally published in 1942.

Bennett, Jane

2001 The Enchantment of Modern Life: Attachments, Crossings, and Ethics. Princeton, N.J.: Princeton University Press.

De Antoni, Andrea, and Paul Dumouchel

2017 "Introduction." In "The Practices of Feeling with the World: Towards an Anthropology of Affect, the Senses and Materiality," special issue, Japanese Review Fujita, Masahiro of Cultural Anthropology 18, no. 1: 91-98. https://doi.org/10.14890/jrca.18.1_91.

2001 "Robotto entāteimento to jinkō chinō" [Robot entertainment and artificial intelligence]. Jinkō chinō gakkai [Journal of Japanese Society for Artificial Intelligence] 16, no. 3: 399-405. https://doi.org/10.11517/jjsai.16.3_399.

Fujita, Masahiro, and Kitano Hiroaki

1998 "Development of an Autonomous Quadruped Robot for Robot Entertainment." Autonomous Robots 5: 7-18. https://doi.org/10.1023/A:1008856824126.

Gershon, Ilana

2015 "What Do We Talk about When We Talk about Animation." Social Media and Society 1, no. 1: 1-2. https://doi.org/10.1177\%2F2056305115578143.

Groove X

n.d. Lovot." Official Website. Accessed January 16, 2019. https://lovot.life.

Gygi, Fabio R.

2018a "Robot Companions: The Animation of Technology and the Technology of Animation in Japan." In Rethinking Relations and Animism: Personhood and Materiality, edited by Miguel Astor-Aguilera and Graham Harvey, 94-111. London: Routledge.

2018 b "Things That Believe: Talismans, Amulets, Dolls, and How to Get Rid of Them." Japanese Journal of Religious Studies 45, no. 2: 423-52. https://doi.org/10.18874/

Hales, Molly jjrs.45.2.2018.423-452.

2019 "Animating Relations: Digitally Mediated Intimacies between the Living and the Dead." Cultural Anthropology 34, no. 2: 187-212. https://doi.org/10.14506/ ca34.2.02. 
Hansen, Paul

2013 “Urban Japan's 'Fuzzy' New Families: Affect and Embodiment in Dog-Human Relationships." Asian Anthropology 12, no. 2: 83-103. https://doi.org/10.1080/168 3478X.2013.852718.

Hardacre, Helen

2017 Shinto: A History. Oxford: Oxford University Press.

Hickey-Moody, Anna

2013 "Affect as Method: Feelings, Aesthetics and Affective Pedagogy." In Deleuze and Research Methodologies, edited by Rebecca Coleman and Jessica Ringrose, 79-95. Edinburgh: Edinburgh University Press.

Hirose, Masato

2002 "Hyūmanoido no yume: 'Tetsuwan Atomu" [The dream of humanoids: Astro Boy]. In Robotto manga wa jitsugen suru ka: robotto manga meisaku ansorojī + robotto kaihatsu saizensen hōkoku [Can robot manga become reality? Anthology of robot manga masterpieces and a report from the front lines on robot development], edited by Y. Yoshihiro, 51-64. Tokyo: Jitsugyō no Nihonsha.

Hoshino, Eiki, and Takeda Dōshō

1987 "Indebtedness and Comfort: The Undercurrents of Mizuko Kuyō in Contemporary Japan.” Japanese Journal of Religious Studies 14, no. 4: 305-20. https://doi. org/10.18874/jjrs.14.4.1987.305-320.

Huizinga, Johan

1970 Homo Ludens: A Study of the Play-Element in Culture. London: Maurice Temple Smith. Originally published in 1938.

Jensen, Casper Bruun, and Anders Blok

2013 "Techno-animism in Japan: Shinto Cosmograms, Actor-Network Theory, and the Enabling Powers of Non-human Agencies." Theory, Culture and Society 30, no. 2: 84-115. https://doi.org/10.1177\%2F0263276412456564.

Katsuno, Hirofumi

2011 "The Robot's Heart: Tinkering with Humanity and Intimacy in Robot-Building." Japanese Studies 31, no. 1: 93-109. https://doi.org/10.1080/10371397.2011.56025 9.

2015 “Branding Humanoid Japan.” In Assembling Japan: Modernity, Technology and Global Culture, edited by Griseldis Kirsch, Dolores P. Martinez, and Merry White, 20530. Oxford: Peter Lang.

Knox, Elena, and Katsumi Watanabe

2018 "AIBO Robot Mortuary Rites in the Japanese Cultural Context." IEEE/RSJ International Conference on Intelligent Robots and Systems (IROS), 2020-2025. https://doi.org/10.1109/IROS.2018.8594066.

Knudsen, Britta Timm, and Carsten Stage

2015 Affective Methodologies: Developing Cultural Research Strategies for the Study of Affect. New York: Palgrave Macmillan.

Kretschmer, Angelika

2000 "Mortuary Rites for Inanimate Objects: The Case of Hari Kuyō" Japanese Journal of Kubo, Akinori Religious Studies 27, no. 3/4: 379-404. https://www.jstor.org/stable/30233671.

2010 "Technology as Mediation: On the Process of Engineering and Living with the 'AIBO' Robot.” Japanese Review of Cultural Anthropology 11: 103-23. https://doi.

Lamarre, Thomas org/10.14890/jrca.11.0_103.

2009 The Anime Machine: A Media Theory of Animation. Minneapolis: University of Minnesota Press.

Latour, Bruno

1993 We Have Never Been Modern. Translated by Catherine Porter. Cambridge, Mass.: Harvard University Press. 
Lindegaard, Jannik Friberg, and Lars Rune Christensen

2018 "Allusive Machines: Encounters with Android Life.” NordiCHI '18: Proceedings of the 10th Nordic Conference on Human-Computer Interaction, 114-24. https:// doi.org/10.1145/3240167.3240189.

Manning, Paul, and Ilana Gershon

2013 “Animating Interaction.” HAU: Journal of Ethnographic Theory 3, no. 3: 107-37. https://doi.org/10.14318/hau3.3.006.

Massumi, Brian

1995 "The Autonomy of Affect." Cultural Critique 31: 83-109. https://doi.org/10. 2307/1354446.

Matsuzaki, Kenzō

1996 "Dōshokubutsu no kuyō oboegaki: kuyōhi konryū shūzoku o megutte" [Memorial services for animals and plants: Concerning the desire for building memorials]. In Minzokuteki sekai no tankyū [Search of the ethnographic world], edited by

Miyazaki, Hirokazu K.H.t.B.A. Committee, 162-85. Tokyo: Keiyūsha.

2004 The Method of Hope: Anthropology, Philosophy, and Fijian Knowledge. Stanford, Calif.: Stanford University Press.

Mori, Masahiro

1981 The Buddha in the Robot. Tokyo: Kosei.

Nagamachi, Mitsuo

1994 "Kansei kōgaku to wa" [What is sense engineering?]. Special issue, Kansei to seni seihin tokushū [Sense and soft products] 50, no. 8: 468-72. https://doi.org/10.2115/ fiber.50.8_P468.

Nagasawa, Toshiaki

1988 "Hari kuyō to Datsueba" [Needle funerary ceremonies and Datsueba]. Seikō minzoku 124: 9-21.

Nishida, Munechika

2018 "Aibo to emoi gijutsu. 'kanjō o shigeki suru sofuto' to shite no robotto" [Aibo and emotional technology: Robots as "emotion-stimulating software"]. AV Watch, March 1. https://av.watch.impress.co.jp/docs/series/rt/1108163.html.

Nozawa, Shunsuke

2013 “Characterization." Semiotic Review 3. https://semioticreview.com/ojs/index.php/ sr/article/view/16.

Ōhashi, Tsutomu, Oda Susumu, Hidaka Toshitaka, and Murakami Yōichiro

1985 Jōcho robotto no sekai [The world of feeling robots]. Tokyo: Kōdansha.

Ōtsuki, Tadashi

2015 "Tsukurareru pātonā: anata + robotto = shiawase?" [A creatable partner: You + robot $=$ happiness?]. Mirai sekkei kaigi [Future Planning Meeting], Japan

Ōuchi, Takako Miraikan, Tokyo, Japan, March 19.

2020 "[Cedec2020] Aibo no 'kashikosa' to 'kawaisa' o tsukuru AI no himitsu [(Cedec2020) The secret of AI building Aibo's intelligence and cuteness]." Morikatron, October Picard, Rosalind W. 21. https://morikatron.ai/2020/10/cedec2020_aibo/.

1995 “Affective Computing." M.I.T Media Laboratory Perceptual Computing Section Rambelli, Fabio Technical Report No. 321. https://affect.media.mit.edu/pdfs/95.picard.pdf.

2007 Buddhist Materiality: A Cultural History of Objects in Japanese Buddhism. Stanford, Rhee, Jennifer Calif.: Stanford University Press.

2018 The Robotic Imaginary: The Human and the Price of Dehumanized Labor. Minneapolis: University of Minnesota Press. 
Robertson, Jennifer

2007 "Robo Sapiens Japanicus: Humanoid Robots and the Posthuman Family." Critical Asian Studies 39, no. 3: 369-98. https://doi.org/10.1080/14672710701527378.

2018 Robo Sapiens Japanicus: Robots, Gender, Family, and the Japanese Nation. Oakland: University of California Press.

Schattschneider, Ellen

2004 "Family Resemblances: Memorial Images and the Face of Kinship." Japanese Journal of Religious Studies 31, no. 1: 141-62. https://doi.org/10.18874/jjrs.31.1.2004.141162.

Seligman, Adam B., Robert P. Weller, Michael J. Puett, and Bennett Simon

2008 Ritual and Its Consequences: An Essay on the Limits of Sincerity. Oxford: Oxford University Press.

Sena, Hideaki

2001 Robotto nijūisseiki [21st century robot]. Tokyo: Bungei Shunjū.

Silvio, Teri

2010 “Animation: The New Performance?” Journal of Linguistic Anthropology 20, no. 2: 422-38. https://doi.org/10.1111/j.1548-1395.2010.01078.x.

2019 Puppets, Gods, and Brands: Theorizing the Age of Animation from Taiwan. Honolulu: University of Hawai'i Press.

Sneath, David, Martin Holbraad, and Morten Axel Pedersen

2009 "Technologies of the Imagination: An Introduction." Ethnos 74, no. 1: 5-30. https://doi.org/10.1080/00141840902751147.

SoftBank

2014 "SoftBank Mobile and Aldebaran Unveil 'Pepper': The World's First Personal Robot That Reads Emotions.” https://www.softbank.jp/en/corp/group/sbm/ news/press/2014/20140605_01/.

Stainova, Yana

2017 "Enchantment as Methodology." Savage Minds, November 1. https://savageminds. org/2017/11/01/enchantment-as-methodology/.

Stone, Jacqueline I.

2003 Original Enlightenment and the Transformation of Medieval Japanese Buddhism. Honolulu: University of Hawai'i Press.

Takeno, Junichi

2011 Kokoro o motsu robotto: hagane no shikō ga kagami no naka no jibun ni kizuku [The robot with soul: A realization of the self in the mirror by a metallic thinking entity]. Tokyo: Nikkan kōgyōsha.

Thomas, Jolyon Baraka

2019a "Domesticity and Spirituality: Kondo Is Not an Animist." Marginalia: Los Angeles Review of Books, February 8. http://marginalia.lareviewofbooks.org/domesticityspirituality-kondo-not-animist/.

2019b "Spirit/Medium: Critically Examining the Relationship between Animism and Animation." In Spirits and Animism in Contemporary Japan: The Invisible Empire, Ukai, Hidenori edited by Fabio Rambelli, 157-70. London: Bloomsbury Academic.

2018 Petto to sōshiki: Nihonjin no kuyōshin o saguru [Pet funerals: Searching for the Wagner, Cosima ceremonial heart of the Japanese]. Tokyo: Asahi Shinbun.

2013 Robotopia Nipponica: Recherchen zur Akzeptanz von Robotern in Japan [Robotopia Nipponica: Research on robot acceptance in Japan]. Marburg, Germany: Tectum Wissenschaftsverlag. 